\title{
ARCHDUKE FERDINAND'S MUSICAL PARNASSUS IN GRAZ
}

\author{
METODA KOKOLE \\ Muzikološki inštitut ZRC SAZU
}

Izvleček: Notranjeavstrijski nadvojvoda Ferdinand ni bil le naslovnik antologije Parnassus musicus Ferdinandaeus - že samo ta je bogat dokument o sirokih glasbenih zanimanjih bodočega cesarja Svetega rimskega cesarstvatemveč je njegov graški dvor zaradi vladarjevega zanimanja za glasbo ter številnih premišljeno načrtovanih družinskih zvez v celoti postal eno izmed vodilnih glasbenih središč v prvih dveh desetletjih 17. stoletja. Razprava prinaša pregledno sliko te zapletene mreže, ki je ustvarila Ferdinandov graški Parnas.

Ključne besede: Gradec, nadvojvoda Ferdinand II., glasbeno mecenstvo, glasbeno središče, začetek 17. stoletja, italijanski glasbeni idiom.

\begin{abstract}
Archduke Ferdinand of Inner Austria was not only the dedicatee of the anthology Parnassus Musicus Ferdinandaeus - in itself a rich document of the future Holy Roman Emperor's wide-ranging musical connections - but his court in Graz also became - on account of his personal music interests and the opportunities provided by carefully planned family connections - a major hub of the leading musical trends of the first two decades of the seventeenth century. The paper provides an overview of this intricate web forming Ferdinand's musical "Parnassus" in Graz. Keywords: Graz, Archduke Ferdinand II, musical patronage, musical centre, early seventeenth century, Italian musical idiom.
\end{abstract}

By 1615 Archduke Ferdinand's court in the Inner-Austrian capital of Graz had been publicly recognised as Parnassus - the mythical home of the nine Muses, symbols of artistic inspiration and goddesses of music, poetry and dance often depicted in artistic works with musical instruments. And indeed: Archduke Ferdinand was by then not only praised for his artistic endeavours expressed in numerous poetical works but also justly acclaimed as a famously generous patron of musicians and promoter of music at large.

This article is intended as a short overview serving as a reminder of, and provider of further insight into, some already-known facts assembled here to establish the wider music framework that led the compiler of the 1615 anthology of small-scale motets to name it "Ferdinand's Musical Parnassus". ${ }^{1}$ It intentionally comes after the political and religious

1 Even though this subject has not yet really been thoroughly researched in recent times, a number of authors dealing with music connected to the Habsburg dynasty have touched on the subject of Ferdinand's archducal musical chapel in Graz and its importance for the development of the later Imperial musical chapel in Vienna. The most important, and later most widely cited, among 
portrait of Ferdinand contributed by Vanja Kočevar ${ }^{2}$ and before the numerous contributions published in the present volume of De musica disserenda that variously explore in some detail selected composers, dedications, musicians and musical compositions forming an integral part of the intricate web of the Graz court chapel and its European connections. ${ }^{3}$

Archduke Ferdinand's residence - his court in Graz - was itself a work of art. It was built in three major phases, starting in the mid-fifteenth century, by his royal Habsburg ancestors, the Holy Roman Emperors Friedrich III and Maximilian I, and his father, the Inner-Austrian Archduke Karl II, all of whom were also known music-lovers and patrons of the arts. The best available artists were engaged to perform the required tasks. The palace together with the church - the court chapel - was commissioned by Friedrich III and after completion became his favourite residence. It was later often used by Emperor Maximilian I, the great-grandfather of Archduke Ferdinand. It was, however, Ferdinand's father, Archduke Karl of Inner Austria, who enlarged the complex to its maximum size, before it slowly fell into disuse following the removal of Ferdinand's court from Graz to Vienna after he was elected Holy Roman Emperor in $1619 .{ }^{4}$

Ferdinand's "Parnassus", however, owed much to the previous efforts of his parents Archduke Karl, educated at the Habsburg Court in Innsbruck, and especially Princess Maria of Bavaria, daughter of the Wittelsbach Duke Albrecht V, whom he had married in 1571. Already in Karl's time the court boasted a distinguished musical establishment that in the words, uttered in 1571, of a contemporary Venetian ambassador "exceeded that of any prince in both quantity and quality". ${ }^{5}$ Although Karl's musical chapel was dissolved after his death in 1590, when Ferdinand was not yet of an age to rule, the latter restored it after 1596 to an even greater splendour and size by virtue, especially, of his inclination towards Italian contemporary music and his engagement of numerous Italian musicians to serve the musical needs of his court.

these is Hellmut Federhofer, especially in his still unsurpassed 1967 monograph Musikpflege und Musiker am Grazer Habsburgerhof der Erzherzöge Karl und Ferdinand von Innerösterreich (1564-1619) and his 1955 article "Graz Court Musicians and their Contributions to the Parnassus musicus Ferdinandaeus (1615)". Among earlier authors, music at the court of Graz had already been considered by Alfred Einstein in 1934 (Einstein, "Italienische Musik", 10-52); more recent contributions have been made by Steven Saunders (1995), and naturally also by authors writing on music in Graz in general, including Federhofer as well as Flotzinger, "Musik in der Steiermark", 30-39, and Staudacher, "Musik in Graz", 670-673. The present article, too, relies greatly on documentation provided by Federhofer and Saunders. Among my own previous articles on the subject, see Kokole, "From Graz to Today's Central Slovenia" (with further literature especially concerning the cultural connections to the southern Habsburg territories effected through the influence and legacy of the Inner-Austrian Governor and Prince-Bishop of Ljubljana Tomaž Hren).

2 Kočevar, "Ferdinand II." (in this volume).

3 See especially the contributions by Marina Toffetti, Klemen Grabnar, Aleksandra Patalas, Herbert Seifert, Katharina Haun, Chiara Comparin, Barbara Przybyszewska-Jarmińska and Peter Király contained in this volume.

4 For a historical overview of Ferdinand's youth and heritage, see, for example, the first chapter of the very recent monograph by Robert Bireley. Bireley, Ferdinand II, 1-60.

5 On this period Federhofer's monograph of 1967 is still unsurpassed. The Venetian ambassador was Giovanni Michieli. See Federhofer, Musikpflege, 23n5. 
Ferdinand's court - like his father's - was in general a sanctuary for music. Secular madrigals, canzonette, villanelle, instrumental canzone, dance music and also sacred vocal chamber music were performed daily in the more or less private setting of rooms lying within the residential part of the palace, ${ }^{6}$ while the court chapel, the church of St Aegidius, today the cathedral of Graz, which was formerly connected via a direct passage to the Archducal residence, witnessed music of the (for those times) greatest quality and scale, including large-scale polychoral compositions by the leading Italian composers of the time, monumental choral compositions in the stile antico, the parody masses so popular at the time,${ }^{8}$ modern concertato compositions with or without obbligato instruments and, last but not least, the then newly fashionable and intimate few-voiced motets, including dialogues and monodies. Fifty-seven pieces of this last-mentioned type form the anthology dedicated to Ferdinand in $1615^{9}$ as representations of the summit of contemporary musical production for his Graz Parnassus.

As I have already mentioned, Ferdinand reactivated the music chapel of his court from 1596 onwards and substantially increased its musical personnel - from 21 members of the chapel in 1596 to 53 in 1619. Italian court musicians were until 1611 mostly recruited from Venice by the chapel master Pietro Antonio Bianco (c. 1540 in Venice - 1611 in Graz). Bianco was already (from 1578) serving Archduke Karl as a Hofkaplan and singer, and was one of the few musicians who remained at the court after Karl's death in 1590. He was undoubtedly a protégé of the Dowager Archduchess Maria and was already in 1595 appointed chapel master. Until his death in 1611 he was the key person responsible for the engagement of new musicians as well as the coordinator of many of the musical dedications addressed to his employer. Good fortune enabled him to engage some of the leading musicians of the time, including composers, for the Graz court chapel. Finally and particularly significantly - he sent some local musicians, for example Georg Poss (c. 1570-post-1633) and Alessandro Tadei (c. 1585-1667), to study music with the foremost Venetian masters, especially Giovanni Gabrieli.

The Graz court chapel was structured hierarchically. ${ }^{10}$ The highest-ranking position

6 The secular repertoire can easily be reconstructed through the various surviving music prints dedicated to Karl, Ferdinand and their courtiers, especially the members of the powerful Khisl family. Federhofer, Musikpflege, 23-54; also Saunders, Cross, Sword, and Lyre, 1-17 and 129-137. For the dedications to his courtiers from Lower Styria and Carniola, see also Kokole, "The Musical Repertoire", 173-181 (identifying further literature).

7 On this repertoire, see Federhofer, Musikpflege, 280-295.

8 See Saunders, Cross, Sword, and Lyre, 38-40 and 61-88, and also some very recent studies by Klemen Grabnar: Grabnar, Parodične maše; Grabnar, Izbrana dela; Grabnar, "From Graz to Ljubljana?"; Grabnar, “Odnos med posvetnim in sakralnim"; and Grabnar, "Litaniarum liber".

9 The complete original edition preserved today in the Museo internazionale e biblioteca della musica di Bologna (I-Bc) is available online through IMSLP (Petrucci Music Library). This very important document concerning the early reception of the Italian monodic style in Austria has only recently been published in a modern edition: Antonicek, Parnassus musicus Ferdinandeus. On Parnassus in general see especially Federhofer, "Graz Court Musicians".

${ }^{10}$ A table of court musicians/composers at the time of the Parnassus Musicus Ferdinandaeus is published in Kokole, "From Graz to Today's Central Slovenia", 338. For details, see Federhofer, Musikpflege, 251-255 and 267-271; and Saunders, Cross, Sword, and Lyre, 225-232. 
was that of the Kapellmeister (chapel master), who had to be a proficient composer. There were two chapel masters in the period under discussion, both Italians: Pietro Antonio Bianco (1595-1611; he was also Elemosinarius) and Giovanni Priuli (from 1614/15 up to the departure of the court musicians to Vienna). A chapel master's responsibilities were: the engagement of court musicians; the acquisition of instruments and printed music; the organisation of court entertainments; and the education of choirboys, in which task he was assisted by the Kapellknabenpräzeptor. Next in rank to the chapel master were the court organists. In 1619, for example, there were three of these, all of them also important composers: Alessandro Tadei (from 1606); Alessandro Bontempo (from 1607); and last but not least Giovanni Valentini (from 1614). In comparison with the number of instrumentalists, the number of choirboys became scaled down in the later years of the Graz chapel. At the time of its relocation in 1619 there were eighteen boys and twenty-three instrumentalists. At the suggestion of the Archduke himself, choirboys were recruited mostly from the Inner-Austrian provinces - including many from Carniola - and, when their voices broke, were granted scholarships for further education. A number of former choirboys later became court instrumentalists. The three especially noteworthy instrumentalists at the Graz court - all of them composers - were Georg Poss (in service from 1607 to 1618), Giovanni Sansoni (from 1613) and Raimundo Ballestra (1602-1616). ${ }^{11}$

The musical repertoire of the court chapel in $\mathrm{Graz}^{12}$ was diligently assembled and supervised by the chapel master in charge. He personally acquired music appropriate for performance before the ruler on different occasions. To this list must be added works ordered from selected composers, especially members of the Musikkapelle, as well as ones dedicated either to the Archduke himself or to his family members and courtiers. The official sacred repertoire of the court can be reconstructed from a number of preserved choirbooks compiled for the needs of the chapel. These were mostly copied by the court bass singer Georg Kuglmann and are today preserved in Vienna, ${ }^{13}$ Graz and Ljubljana. ${ }^{14}$ Further information on the musical repertoire of the Graz court can be gleaned from the preserved inventories of music, especially two lists dating from 1590 and 1672, respectively. ${ }^{15}$ The inventories and choirbooks principally contain information on the sacred repertoire, while the publications dedicated to court officials and the compositions of the court musicians themselves evidence the variety of musical genres performed at the court. These published compositions include a smallish number of secular works, notably ones by Pietro Antonio Bianco, Matthia Ferrabosco, Francesco Stivori, Bartolomeo Mutis and Giovanni Valentini. Allowing for the presence of older Flemish music, headed by

${ }^{11}$ For Ballestra's links to Giovanni Gabrieli and Venetian music, see Kokole, "Echoes of Giovanni Gabrieli's Style", 52-53.

${ }^{12}$ For a general overview, see Federhofer, Musikpflege, 45-46; and Saunders, Cross, Sword, and Lyre, 38-40 and 119-137.

${ }^{13}$ For selected Viennese codices, see Saunders, Cross, Sword, and Lyre, 38-57.

${ }^{14}$ For the Graz court repertoire today kept in Ljubljana, see the new findings and identifications of composers and copyists contained in Grabnar, Parodične maše, Grabnar, Izbrana dela, and especially Grabnar, "From Graz to Ljubljana?".

${ }_{15}$ The last one, dated 1672, is an inventory of the Court Archive in Graz. Federhofer, Musikpflege, 286-295. 
compositions of Orlando di Lasso, Italian and especially Venetian composers of the late sixteenth and early seventeenth centuries are prominently represented.

According to present knowledge, around twenty collections were written for, dedicated to or indirectly presented to Archduke Ferdinand and his family from about 1597 up to 1619. Only six of the listed collections contain secular music, all the others featuring sacred works. Ferdinand's preferences and strategy to defeat Protestantism also by employing musical means are well illustrated by this list (see the list in the Attachment). Among the names of the principal composers and editors - marked in bold in my list - are

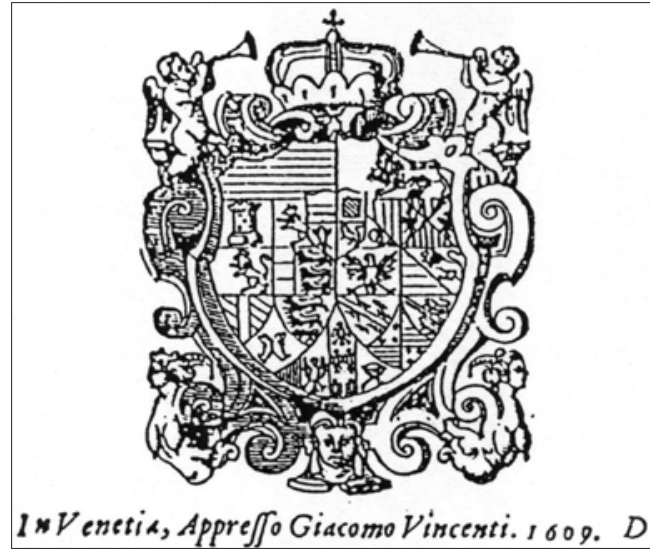

Figure 1

Archduke Ferdinand's coat-of-arms taken from the title page of Gabriello Puliti's Baci ardenti (1609; Biblioteca nazionale centrale, Florence [I-Fn], Mus. Ant. 16; after Monumenta artis musicae Sloveniae, 44 [with kind permission]) ten names directly linked to the court chapel in Graz (anthologies are excluded from this computation). The presence of the leading court musicians - Simone Gatto, Annibale Perini, Raimundo Ballestra, Giovanni Valentini and Giovanni Priuli - is hardly surprising.

Some of the composers were "direct" dedicators, while others acted on the advice of - for example - the court chapel master (this is true, for instance, of Orazio Vecchi's Il convito musicale, a collection of witty madrigals, canzonette, dialogues etc. published in 1597, which came about through a recommendation from Pietro Antonio Bianco), ${ }^{16}$ or else were dedicated instead by the publisher (for example, Giacomo Vincenti, who in 1610 dedicated to Ferdinand Viadana's Sinfonie sacrae). Some other works were actually addressed to Ferdinand in the role of a merely "collateral" dedicatee for the sake of a major financial reward, as was the case with Tomas Luis de Victoria's Masses, Magnificat, motets and psalms of 1600. This print was dedicated officially to the Spanish King Philip III; ${ }^{17}$

${ }^{16}$ Vecchi, Convito musicale. The dedicatory letter concludes: "E mi giova di sapere, che esso le debba essere non affatto discaro, poiche alli giorni passati il M. Reuer. Sig. D. Pietro Antonio Bianchi Maestro di Capella, \& Elemosinario di V. A. mi disse ch'ella si compiace alle volte di passeggiare co i piedi del suo purgato vdito per la mia SELVA di varia ricreatione. Talche s'ella s'è degnata di gustar frutti Selvatici, vengo in speranza, ch'ella sia per gustar maggiormente queste viuande condite col sale della ciuile harmonia; Cosi voglia la mia buona fortuna, che il mio CONVITO habbia tal sapore, che possa adescare il suo delicato gusto, e produre in Lei quell'effetto di far l'inuito à V. A. con vua particolar deuotione verso di Lei, Allaquale incinandomi con ogni debita riuerenza, a me le raccomando in gratia."

${ }^{17}$ See Appendix. 
the latter was, however, related to Ferdinand through his wife Margareta, Ferdinand's sister, whom he married in $1599 .{ }^{18}$

All the dedicatory letters without exception heap praises on Ferdinand's religious devotion, high musical standards, exquisite musical taste, generosity and protection of capable musicians. Protection under the wings of the "Great Eagle" was, for example, openly sought by Gabriello Puliti (c. 1583-1644), then organist at the cathedral of Koper and member of an academy, who in 1609 dedicated "Al Sereniss[imo] Prencipe Ferdinando Arciduca d'Austria, etc." his second book of madrigals, entitled Baci ardenti. ${ }^{19}$ This collection also contains two secondary dedications indicated above two of the madrigals - L'Aura de merti tuoi and Ecco di mill'e mille - which are dedicated to Archduke Maximilian Ernest of Austria, Ferdinand's younger brother, who died in 1616. ${ }^{20}$

Another interesting example is a collection of Latin motets, Motectorum, for four to eight, ten and twelve voices by two already deceased court composers, Simone Gatto and Annibale Perini, ${ }^{21}$ published in 1604 by Orazio Sardena, court trumpeter and cornettist. ${ }^{22}$ Orazio Sardena dated the introductory text containing the dedication in Graz on 1 March 1604 and sent it to Venice for printing by Ricciardo Amadini. We learn from Sardena's dedication that Gatto and Perini had been his good friends and fellow musicians under Ferdinand's father Karl, and that Gatto had also taught him. He praises Ferdinand's musicians of "all kinds" likening them and their Christian piety to David with his lyre, and he naturally does not fail to compliment Ferdinand on his patronage and generosity. ${ }^{23}$ Some

${ }^{18}$ See footnote 31 , below.

19 The collection was edited by Bojan Bujić in 2003 in Puliti, Baci ardenti (1609), 1-85. The letter of dedication was dated 25 February 1609 at Venice by the composer, and the collection was printed by Giacomo Vincenti. The edition is embellished on the title page with Ferdinand's coatof-arms, another sign of great reverence. Here is the passage in which Puliti seeks protection: "Perilche stando in me stesso un giorno frà gli altri, mi venne in pensiero (havendo già inteso quanto sia vaga dell'arte, et numeri armonici) di comporre li presenti Madrigali, intitolati BACI ARDENTI, atti per aventura ad esprimer la mia devota servitù, et l'animo mio affettuoso verso il merito di V. Altezza Serenissima, la quale non sdegnerà, che restino segnati nella fronte del suo temuto, et riverito nome, per assicurarli sotto l'ali di sì grand'AQVILA da gli oltraggi del tempo, et del'ingiuria delle male lingue."

${ }^{20}$ Maximilian's name actually appears also in the texts of both madrigals. See the comments by Bojan Bujić in his edition: Puliti, Baci ardenti (1609), XXIV and 69-80 (the music of both madrigals).

${ }^{21}$ Gatto and Perini, Motectorum.

${ }^{22}$ Federhofer, Musikpflege, 129-131.

23 " [...] Atque mihi certum est munus hoc etsi levidense et opus exiguum, ac tanto Archiduce forsitan indignum, eundem tamen, quem in Musicis velut alterum Regium psalten cum cantoribus decantatnem et citharis pulsantem Davidem totus personat Christianus orbis, omnis generis Musicorum Archiducem seu etiam divinum quempiam Orpheum ex siderum arce ad terram demissum silvarum arbores saxaque montium et cuncta ad se viventia suavissimo suo instrumentorum ac totius generis Musicorum concentu trahentem vestram luce meridiana longè splendidiorem conspicit, admiratur, predicat serenitatem. Uterque superstes adhuc Author praefatus Paternae Musices Patronum Archidicem et Mecaenatem Principem esse summis apud supremum Dominum votis exposcebat gaudens Serenitatem vestram atqui praeventus mortalitate hanc mihi unico provinciam unice demandavit uterque. Feci itaque Serenissimè Archidux hoc 
of the pieces are in dialogue form, and some for two choirs. One is even a dialogue for twelve voices in Italian: Gatto's Hor che la noua vaga primavera. This selection of polychoral sacred music in dialogue form by two favoured court instrumentalists presented alongside a pastoral polychoral dialogue in Italian undoubtedly reflects both the authors' training in the Venetian style ${ }^{24}$ and Ferdinand's personal inclination towards such music, an inclination actually also evident from other extant musicalia of the Graz court chapel. This anthology concludes with Perini's monumental twelve-part Kyrie eleison.

Before I say a few more words about the dedication and the collection Parnassus Musicus Ferdinandaeus, published approximately four hundred years ago, let me introduce another particularly interesting and exceptionally fine item from the mentioned list: Musica Austriaca, a collection of nineteen madrigals composed in the summer of 1604 by Ferdinand's court organist Francesco Stivori, who had been recruited for the Graz chapel, probably by Pietro Antonio Bianco, in 1602. The dedicatory letter addressed to the "Serenissima et alta Principessa Madamma Maria", born Duchess of Bavaria but now Archduchess of Austria, ${ }^{25}$ was signed in Venice on 15 February 1605, shortly before the composer's death. This collection, which survives incompletely (only nine out of a probable twelve partbooks being extant), was printed in Venice by Ricciardo Amadino. ${ }^{26}$

From the dedication we learn that the music was actually commissioned by Maria's children, the "Altezze Serenissimi de Principi et Principesse", apparently in order to please their mother, and that the music was performed to celebrate Maria's recovery from some illness; possibly - as already mooted by Alfred Einstein - as intermedia for a pastoral drama performed during the visit to Graz of her brother, Wilhelm V of Bavaria. ${ }^{27}$ Stivori explains that he had composed the pieces during the previous summer and expresses his gratitude for the prestigious task entrusted to him. Taken as a whole, the collection is a worthy monument to the archducal house of Graz, Maria's "Casa Sua", as much on account of its formal organisation as for its musical contents.

Twelve out of the nineteen madrigals in Musica Austriaca are encomiastic and glorify the "incomparable grandeur and virtues" (gl'incomparabili grandezze et virtudi) of the living and the more important deceased members of the family (see the list below). Seven pieces appearing at the end of the collection, all dedicated to Ferdinand, are settings of

atque omnium Motectorum Utrius praedicti opus nunquam simul aut ante visum in unum Collegi et Serenitati vestra mea summum erga Serenitatem vestram deuotionis et observantiae affectum intuendum dicaui. Cuius arbitrio ac tutelae hoc munus xenij ergo, mea omnia et memetipsum demum commendo atque trado. [...]" Passage from the dedicatory letter of Gatto and Perini in Motectorum.

${ }^{24}$ An indebtedness to Giovanni Gabrieli is clear from the structure of the motets and in addition through the choice of texts and subjects. On Gabrieli's legacy and its influence on the Graz court repertoire, see also Kokole, "Echoes of Giovanni Gabrieli’s Style", 51-57.

${ }^{25}$ On Archduchess Maria, see footnote 29, below. Ferdinand, together with his mother, was the dedicatee also of an anthology compiled by Vincenzo Lilius in Cracow in 1605. The dedication is transcribed in Szweykowska and Szweykowski, Włosi w kapeli królewskiej, 248-249.

${ }^{26}$ Stivori, Musica Austriaca. The British Library, London (GB-Lbl) holds a complete set of parts for the third choir, while an assortment of parts from three of the choirs is preserved in the Staats- und Stadtbibliothek, Augsburg (D-As) (I: S, A; II: S, T, B; III: S, T).

${ }^{27}$ Einstein, "Italienische Musik", 48. 


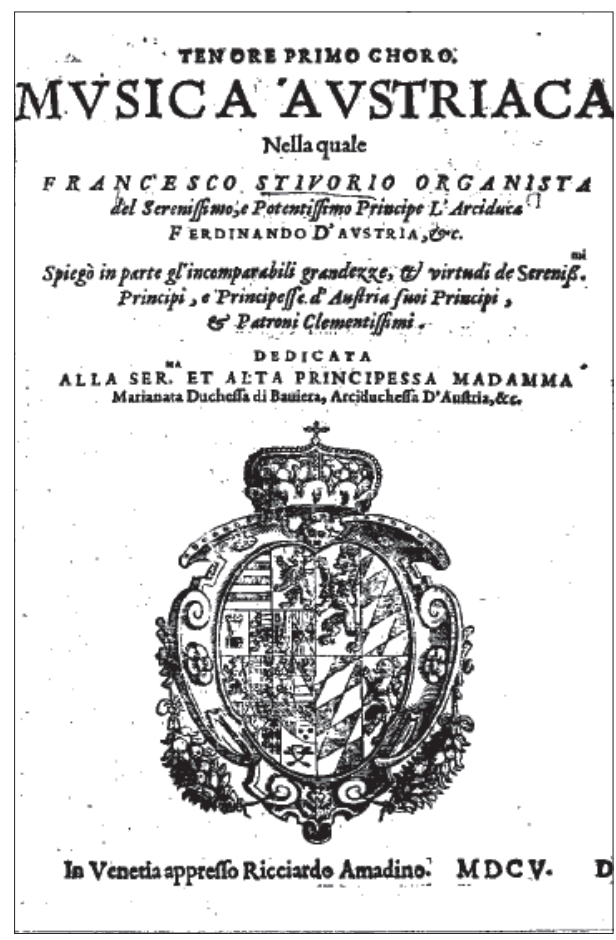

\section{Figure 2}

Title page of Francesco Stivori's Musica Austriaca (1605; D-As, Tonk Schl 145 [with kind permission])

pastoral poetry. The dedicatee, Maria, is appropriately praised in the opening piece, Serenissima Donna. The following madrigal praises the ruler (and possibly commissioner), Archduke Ferdinand. This is - also appropriately for Ferdinand's position at the court - the only piece for sixteen voices, probably distributed among four choirs. These two pieces are followed by seven eight-part madrigals for two choirs, each praising Maria's other children. Foremost among them is $\mathrm{Il}$ bel Augusto volto in honour of Archduchess Margareta, then holding a supreme position as Queen of Spain. The only person celebrated who had already died by that time is Archduchess Anna, who breathed her last as Queen of Poland in $1598^{28}$ She is celebrated with a madrigal, Per te donna Reale. Maria's only child to be praised in more than one composition is her youngest son, who was possibly the closest to her heart, since he had been born after her husband's death and named Karl after his father. This new Karl later became Bishop of Passau and Strasbourg and Archduke of Outer Austria. Musica Austriaca is indeed a collection worthy to celebrate a musical family of royal patrons - and is fittingly distinguished by a printed family coat-of-arms on the title page.

The list of Maria's children praised in the Musica Austriaca is also most informative for a discussion of the family's European contacts, since music and musicians were regularly exchanged between Ferdinand's court in Graz (from 1619 in Vienna) and the various courts where his family members were either intimately connected with the rulers or ruling themselves. We find there: (i) Ferdinand's uncles, who were rulers in Innsbruck, Vienna and Prague; (ii) members of his mother's family, the Bavarian Wittelsbachs with their court in Munich (made famous especially by the presence there of Orlando di Lasso, Maria's music teacher and friend); ${ }^{29}$ (iii) his own brothers and sisters, whose political

${ }^{28}$ See footnote 30 , below.

${ }^{29}$ The literature on the musical endeavours of Maria of Bavaria is relatively abundant. Most recent are the following studies: Koldau, Frauen - Musik-Kultur, 69-79; and Keller, Erzherzogin Maria 
and religious positions had been carefully planned by their father, Archduke Karl, and Archduchess Maria; and lastly (iv) Ferdinand's relatives acquired through his two marriages. In 1600 he wedded his cousin Maria Anna of Bavaria - thereby strengthening contacts with the Munich court chapel even further - and in 1622 the Medici Princess Eleonora from the Tuscan court.

Internal dedications in the Musica Austriaca by Francesco Stivori (1605)

\section{Madre Madamma Maria nata Duchessa di Baviera (1551-1608) $\rightarrow$ Bavarian court Serenissima Donna, a 8; 2 choirs}

2. Arciduca Ferdinando $(1578-1637) \rightarrow$ Inner Austrian court; later Imperial court Selve beate e care, a 16; 4 choirs

3. Arciduchessa Maria Anna (1573-1598) $\rightarrow$ Polish court Per te Donna Regale, a 8, 2 choirs

4. Arciduchessa Maria Christierna (1574-1621) $\rightarrow$ Transylvanian court Questa ch' in tanti raggi, a 8, 2 choirs

5. Arciduca Massimiliano (Maximilian Ernst, 1583-1616) Poiche dall'Indo al Tile, a 8, 2 choirs

6. Arciduchessa Leonora (Eleonora, 1582-1620) Nimfe leggiadre, a 8, 2 choirs

7. Arciduchessa Margarita, hoggidì Regina di Spagna (1584-1611) $\rightarrow$ Spanish court Il bell' Augusto volto, a 8, 2 choirs

8. Arciduca Leopoldo (1586-1632) $\rightarrow$ Bishop of Passau and Strassbourg Scetro Manto, e Corona, a 8, 2 choirs

9. Arciduchessa Maddalena (1589-1631) $\rightarrow$ Tuscan court L'animosa Latina, a 8, 2 choirs

10. Arciduchessa Constanza (1588-1631) $\rightarrow$ Polish court Il magnanimo cor, a 8, 2 choirs

11. \& 12. Arciduca Carlo (the Posthumous, 1590-1624) $\rightarrow$ Bishop of Wroclaw and Brixen O Carlo pargoletto \& Ben delle gratie prendi, a 8 \& a 16, 2 \& 3 choirs

13.-19. Arciduca Ferdinando (seven pastoral madrigals a 12 for 3 choirs)

Two of Ferdinand's sisters were married in succession to the Polish King Sigismund III: first Archduchess Anna in 1592, and then in 1605 Archduchess Constanza. ${ }^{30}$ The exchange of musicians between the court of Graz and those of Warsaw and Munich is actually rather well documented. The family succeeded also in marrying his two other sisters to mighty rulers of the "Latin" world. Margareta became Queen of Spain, Portugal, Naples and Sicily in 1599, subsequently also consort of the ruler of Milan, ${ }^{31}$ and in 1608 the reportedly beautiful, lively and most pious Maria Magdalena married the future Grand

von Innerösterreich (1551-1608). On the musical relations between the courts in Munich and Graz and their influence on other Inner-Austrian regions, see also Kokole, "Musical Repertoire".

${ }^{30}$ On the musical relations between the Graz court and the Polish royal court, see Federhofer, "Musikalische Beziehunegen"; Szweykowska and Szweykowski, Włosi w kapeli królewskiej, 16-21 (on the marriage of 1592); and Przybyszewska-Jarmińska, History of Music in Poland, $57-80$.

${ }^{31}$ For more documentation on this wedding, see Antonicek, "Italienische Musikerlebnisse", 108-109. 
Duke of Florence, Cosimo II. ${ }^{32}$ Margareta and Maria Magdalena remained alike closely connected to their brother and to their native Graz. Ferdinand's brothers, too, achieved influence through their ecclesiastical posts and associated chapels.

In view of all these important European connections forged by Ferdinand's musicloving family, it comes as no surprise that his native home in Graz was termed in 1615 "Ferdinand's Musical Parnassus". The extensive print with this title was published by the Venetian printer Giacomo Vincenti. ${ }^{33}$ It was compiled by Giovanni Battista Bonometti (or Buonometti), then a tenor singer at the Graz court chapel. It came out in five partbooks: Cantus, Altus, Tenor, Bassus and Partitura, the last-named volume providing the instrumental bass in two alternative forms: as a Partitura on two staves (the lower for basso and the upper, untexted, for one of the vocal parts) and as a single figured bass line called Basso Continuo or Basso Principale.

In Bonometti's dedication, dated 30 April 1615 in Graz, the Court is referred to as the "Parnassus", thereby alluding to the Archduke's role as promoter and patron of the arts. ${ }^{34}$ Bonometti also refers to Milanese friends who had encouraged him to undertake such an enterprise. ${ }^{35}$ His contact with a Milanese music circle comes, of course, as no surprise, considering that Ferdinand's sister Margareta was the consort of the ruler in Milan and that four Milanese musicians had been engaged for Ferdinand's marriage to Maria Anna of Bavaria in Graz in $1600 .{ }^{36}$ We also learn from this dedication that the best Italian and other musicians serving Ferdinand in Graz had been asked to contribute music, in addition to some of the most illustrious composers in Italy itself.

Out of 32 composers, nine were Graz court musicians, including some South-German

32 On Maria Magdalena's Florentine marriage, see Carter, "Florentine Wedding of 1608".

${ }^{33}$ Bonometti, Parnassus musicus Ferdinandaeus (RISM 1615 $5^{13}$ ); and Antonicek, Parnassus musicus Ferdinandeus (the complete modern edition). The most exhaustive study on this anthology remains Federhofer, "Graz Court Musicians". See also Saunders, Cross, Sword, and Lyre, 129-137. Some individual motets have been published earlier also in Priuli, Vier Generalbaßmotetten; and Saunders, Fourteen Motets.

34 "Musica, quae ex mente Aristotelis est ex iucundissimis, quae sunt secundum naturam, quod motibus naturalibus delectari datum sit omnibus a natura, et inter motus ille sit naturae familiarior, qui est ordinatus. Quare Serenissime Ferdinande, ut honestissimam, tantoque Principe dignam, quam Musice studio hauris voluptatem augerem hunc Parnassum Musicum Ferdinandaeum congerendum, tuaeque Serenitati consecrandum esse iudicavi. Offero ergo montem Musicum, ut Musicae suavissimis irritamentis in illo frui quaeas. [...] Tam suavis, mihi crede, Serenissime Ferdinande, ex hoc monte harmonia etiam ad dissitas Italia urbes diffunditur, ut omnis illarum in Musica suavitas insuavis, concinnitas inconcinna videatur."

35 "Ut Vero Serenitatis tuae aura prouocatus Graecium veni, ut harmonicos vocum concentus, quos sola fama ante cognoram, auribus hausi, statim in hanc mentem suauiviolentia sum pertractus, ut (quod alias Mediolani amicorum armatis precibus persuasus aggressus fueram) seligerem optimorum mela suavissima, et latialibus cygnis Graecensis Philomelas tuas, quasi coronae gemmas infererem, et publicum productas in Parnassum Musicum Ferdinandeum magni tui nominis titulo gloriosum, collocarem." On the composers of the Lombard region, see also the contributions by Marina Toffetti ("Da Milano a Graz") and Chiara Comparin ("Il secondo libro") in the present volume.

${ }^{36}$ Dominico Moeta, Alexandro Morat, Damiano Marcellin and Lorenzo Arrihin. See Federhofer, “Graz Court Musicians", 172n15. 


\section{Figure 3}

Verso of the title page of the Parnassus Musicus

Ferdinandaeus (1615; available online on http://imslp.org)

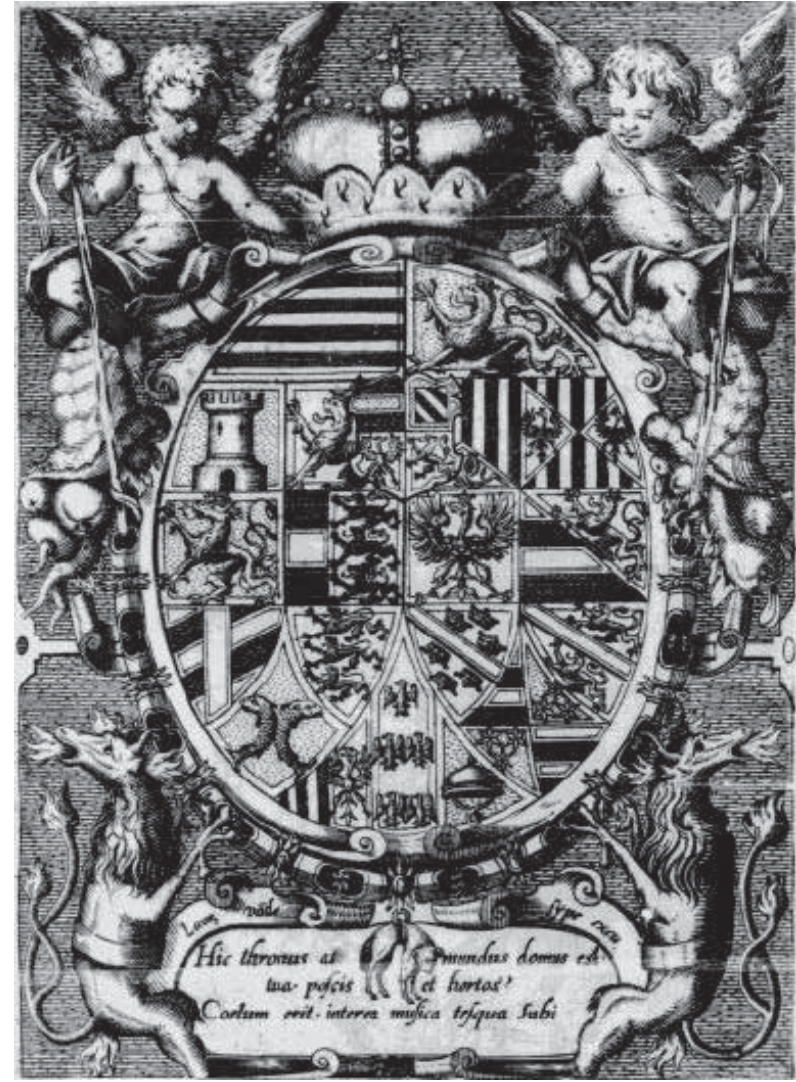

and Austrian composers, such as Georg Poss (represented in the anthology with two motets), Raimundo Ballestra (four motets) and Alessandro Tadei (one motet). Still, most of the composers were Italians: characteristically, in quantitative terms Giovanni Valentini heads the list with five motets (Benedicam Dominum for bass, O Maria, quid ploras ad monumentum, and Deus Misereatur nostri both for soprano and bass, $O$ dulcis amor Jesu for soprano, tenor and bass, and Vulnerasti cor meum for two tenors and bass). Valentini is followed by Giovanni Priuli with four motets, Bartolomeo Mutis, Michelangelo Rizzi, Giovanni Sansoni (all represented by two pieces), and Alessandro Bontempo (one motet). ${ }^{37}$

Alphabetical list of composers in the Parnassus Musicus Ferdinandaeus

\begin{tabular}{|l|r|}
\hline Composer & Number of motets and voices \\
\hline Arnone, Guglielmo & 1 a 4 \\
\hline Ballestra, Raimundo & 1 a 3 \& 1 a 4 \\
\hline Barbarino, Bartolomeo "il Pesarino" & 1 a 1 \\
\hline
\end{tabular}

37 On Sansoni, see also the Herbert Seifert's contribution "Giovanni Sansoni"; and on Cocciola that by Aleksandra Patalas, "Giovanni Battista Cocciola's Activity" (both in this volume). 


\begin{tabular}{|c|c|}
\hline Composer & Number of motets and voices \\
\hline Biumi, Giacomo Fillippo & $1 \mathrm{a} 2$ \\
\hline Bontempo, Alessandro & $1 \mathrm{a} 2$ \\
\hline Borgo, Cesare & $1 \mathrm{a} 4$ \\
\hline Brignoli, Giacomo & 1 a $3 \& 1$ a 4 \\
\hline Casati, Francesco & 1 a $2 \& 1$ a 4 \\
\hline Cavaccio, Giovanni & 1 a $1 \& 1$ a 4 \\
\hline Cima, Andrea & 1 a 3 \\
\hline Cocciola, Giovanni Battista & 1 a 3 \\
\hline Coda, Federico & $1 \mathrm{a} 2 \& 1$ a 4 \\
\hline Comanedo, Flaminio & $1 \mathrm{a} 4$ \\
\hline Coradini, Niccolò & 1 a 1 \\
\hline Gabutio (Gabussi), Giulio Cesare & $1 \mathrm{a} 2$ \\
\hline Ghizzolo, Giovanni & 1 a $3 \& 1$ a 4 \\
\hline Monteverdi, Claudio & $1 \mathrm{a} 2$ \\
\hline Mutis, Bartolomeo (Conte di Cesana) & $2 \mathrm{a} 2$ \\
\hline Nanterni, Horatio (Orazio) & $1 \mathrm{a} 4$ \\
\hline Osculati, Giulio & $1 \mathrm{a} 4$ \\
\hline Pasti, Giovanni & $1 \mathrm{a} 2$ \\
\hline Pellegrini, Vincenzo & 1 a $1 \& 1$ a $2 \& 1$ a $3 \& 1$ a $4 \& 1$ a 5 \\
\hline Poss, Giorgio (Georg) & 1 a $2 \& 1$ a 4 \\
\hline Priuli, Giovanni & 2 a $1 \& 1$ a $2 \& 1$ a 4 \\
\hline Re, Benedetto & $2 \mathrm{a} 2$ \\
\hline Rizzi (Rizzio), Michelangelo & 1 a $2 \& 1$ a 3 \\
\hline Rognoni, [Giovanni?] Domenico & 1 a $2 \& 1$ a 4 \\
\hline Sansoni, Giovanni & $2 \mathrm{a} 2$ \\
\hline Sirena, Galeazzo & $1 \mathrm{a} 2$ \\
\hline Tadei, Alessandro & 1 a 3 \\
\hline Turini, Francesco & 1 a 1 \\
\hline Valentini, Giovanni & 1 a $1 \& 2$ a $2 \& 2$ a 3 \\
\hline
\end{tabular}

The importance of the Parnassus Musicus Ferdinadaeus lies not only in the fact that it transmits a cross-section of the motet repertoire performed and composed at the Archduke's court in Graz in the middle of the second decade of the seventeenth century, but also in the fact that it constitutes, along with the Musiche a una, doi e tre voci by Bartolomeo Mutis, conte di Cesana, (1613) $)^{38}$ and a collection of concertato motets for two to eight voices by Heinrich Pfendner (1614), one of the earliest collections of sacred concertos for a few voices with basso continuo printed north of the Alps - an anthology that paved the way for the early Baroque sacred style in the Austrian lands at large. ${ }^{39}$

${ }^{38}$ For a further discussion of this collection, see Katharina Haun's contribution "Music by Bartolomeo Mutis" in the present volume.

${ }^{39}$ For a discussion of early sacred monody of this type in other Inner-Austrian centres and beyond, see also Kokole, "Venetian Influence", and Kokole, Isaac Posch, 177-235 (a chapter on a similarly structured collection of 1623, Harmonia Concertans). See also the contributions by Barbara 


\section{Appendix}

The list of known musical homages to Archduke Ferdinand and his family in Graz (1597-1619)

$1597^{40} \quad$ Orazio Vecchi: Convito musicale nel quale si contengono varij sogetti, et capricci, a tre, quattro, cinque, sei, sette, \& otto voci, novamente composto, \& dato in luce. (RISM V 1050)

1598 Antonio Mogavero: Il III. Libro de madrigali a 5 voci intitolati Vezzi amorosi. [indirect evidence through payment] (RISM M 2919)

1600 Tomás Luis de Victoria: Missce Magnificat, Motecta Psalmi, \& alia qua[m] plurima. [printed in Madrid; dedicated to Philip III, King of Spain; indirectly also to Ferdinand, as evidenced by a letter accompanying the collection sent to Graz] (RISM V 1435)

1603 Jacob Regnart: Corollarium missarum sacrarum, ad imitationem selectissimarum cantionum suavissima harmonia a quatuor, quinque, sex, octo \& decem vocibus. [printed in Frankfurt] (RISM R and RR 736)

1604 Lambert de Sayve: manuscript "Mass" and "Magnificat" [indirect evidence through payment] (RISM 540200492 and 540200450)

1604 Simone Gatto and Annibale Perini: Motectorum IIII. V. VI. VII. VIII. X. \& XII. vocibus Simonis Gatti [...] tum Annibalis Perini [...] insequens opus hoc levidense noviter collectorum, autore Horatio Sardena. [edited by Orazio Sardena] (RISM G 575)

1604 Melodiae sacrae [printed in Cracow, edited by Vincenzo Gigli (Lilius); contributions by various court musicians of King Sigismund III of Poland] (RISM 1604²)

$1605 \quad$ Francesco Stivori: Musica austriaca. (RISM S 6456)

1607 Georg Poss: Liber primus missarum octonis et senis vocibus. [printed in Graz] (RISM P 5245)

1607 Georg Poss: Orpheus mixtus vel, si mavis concentus musici, tam sacris, quam profanis usibus elaborati, tam simulatis instrumentorum [...] quibus vox octava initium sextadecima finem scribit. [printed in Graz] (RISM P 5246)

1609 Pietro Antonio Bianco: Sacri concentus octonis vocibus, tum vivae vocis, tum omnium instrumentorum genere decantandi. (RISM B and BB 2595)

1609 Gabriello Puliti: Baci ardenti. Secondo libro de' madrigali a cinque voci. (RISM P 5649)

Przybyszewska-Jarmińska ("Music-Related Contacts”), Peter Király ("Foreign Musicians”), Rudolf Flotzinger ("Monastic Manuscript Parallel") and Martin Fiala ("P. Sebastian Ertel") in the present volume.

${ }^{40}$ Published in Venice unless stated otherwise. The present list is mostly based on documentation given in Federhofer, Musikpflege, 46-47. 
1610

1610

1611

1613

1613

1615

1616

1618 and 1619 Giovanni Priuli: Sacrorum concentuum [...] in duas partes distributorum, pars prima [and] pars altera. (RISM P 5476 and 5477)

\section{Bibliography}

\section{EARLY PRINTS}

Bonometti, Giovanni Battista, ed. Parnassus musicus Ferdinandaeus. Venice: Giacomo Vincenti, 1615. RISM $1615^{13}$.

Gatto, Simone, and Annibale Perini. Motectorum IIII. V. VI. VII. VIII. X. \& XII. vocibus Simonis Gatti [...] tum Annibalis Perini [...] insequens opus hoc levidense noviter collectorum, autore Horatio Sardena. Venice: Ricciardo Amadini, 1606. RISM G 575.

Puliti, Gabriello. Baci ardenti. Secondo libro de' madrigali a cinque voci. Venice: Giacomo Vincenti, 1609. RISM P 5649.

Stivori, Francesco. Musica austriaca nella quale Francesco Stivorio [...] spiegò in parte gl'incomparabili grandezze, \& virtudi de Sereniss ${ }^{\text {mi }}$ principi, e principesse d'Austria. Venice: Ricciardo Amadini, 1605. RISM S 6456.

Vecchi, Orazio. Convito musicale nel quale si contengono varij sogetti, et capricci, a tre, quattro, cinque, sei, sette, \& otto voci, novamente composto, \& dato in luce. Venice: Angelo Gardano, 1597. RISM V 1050. 


\section{LITERATURE}

Antonicek, Theophil. "Italienische Musikerlebnisse Ferdinands II. 1598”. In Anzeiger der Österreichischen Akademie der Wissenschaften, 104, 91-111. Mitteilungen der Komission für Musikforschung, 18. Vienna: Österreichische Akademie der Wissenschaften, 1968.

___ ed. Parnassus musicus Ferdinandeus: herausgegeben von Giovanni Battista Bonometti (1615). Denkmäler der Tonkunst in Österreich, 159. Graz: Akademische Druck- u. Verlagsanstalt, 2015.

Bireley, Robert. Ferdinand II: CounterReformation Emperor, 1578-1637. Cambridge: Cambridge University Press, 2014. https://doi.org/10.1093/ahr/120.5.1992.

Carter, Tim. “A Florentine Wedding of 1608”. Acta musicologica 55 (1983): 89-107. http:// dx.doi.org/10.2307/932663.

Einstein, Alfred. "Italienische Musik und italienische Musiker am Kaiserhof und an den erzherzoglichen Höfen in Innsbruck und Graz”. Studien zur Musikwissenschaft 21 (1934): 3-52.

Federhofer, Hellmut. "Graz Court Musicians and their Contributions to the Parnassus musicus Ferdinandaeus (1615)". Musica Disciplina 9 (1955): 189-244.

___ " "Musikalische Beziehungen zwischen den Höfen Erzherzog Ferdinands von Innerösterreich und König Sigismunds III. von Polen". In The Book of the First International Musicological Congress Devoted to the Works of Frederick Chopin, Warszawa 16th-22nd February 1960, edited by Zofia Lissa, 522-526. Warsaw: Polish Scientific Publishers PWN, 1963.

___ " "Musikleben in der Steiermark". In Die Steiermark. Land, Leute, Leistung, edited by Gernot D. Hasiba and Berthold Sutter, 614-660. Graz: Steiermärkischen Landesregierung, 1971,

___ Musikpflege und Musiker am Grazer Habsburgerhof der Erzherzöge Karl und Ferdinand von Innerösterreich (1564-1619). Mainz: B. Schott’s Söhne, 1967.

Federhofer, Hallmut, and Rudolf Flotzinger. "Musik in der Steiermark - historischer Überblick”. In Musik in der Steiermark. Katalog der Landesausstellung 1980, edited by Rudolf Flotzinger, 15-83. Graz: Styria, 1980.

Grabnar, Klemen. "From Graz to Ljubljana? Towards Discovery of the Origin of the Hren Choirbooks". De musica disserenda 11, no. 1-2 (2015): 211-227. https://doi. org/10.3986/dmd11.1-2.13.

___ - ed. Izbrana dela iz Hrenovih kornih knjig / Selected Works from the Hren Choirbooks. Vol. 1, Annibale Perini, Missa Benedicte omnia opera Domini \& Pietro Antonio Bianco, Missa Percussit Saul mille. Monumenta artis musicae Sloveniae, 62. Ljubljana: Založba ZRC, ZRC SAZU, 2017.

. "Odnos med posvetnim in sakralnim v drugi polovici 16. stoletja na primeru maš Nasce la pena mia Bartolomea Spontoneja in Costanza Antegnatija" [Secular and Sacred in the Second Half of the Sixteenth Century: The Case of Masses Nasce la pena mia of Bartolomeo Spontone and Costanzo Antegnati]. Muzikološki zbornik 50, no. 2 (2014): 181-198. https://doi.org/10.4312/mz.50.2.181-198.

. Parodične maše v Hrenovih kornih knjigah [Parody Masses in Hren Choirbooks]. PhD diss., Univerza v Ljubljani, 2015. 
. "The Litaniarum liber (SI-Lnr, Ms 344): Transmission of Musical Litanies from Graz to the Duchy of Carniola". In Music Migration in the Early Modern Age: Centres and Peripheries; People, Works, Styles, Paths of Dissemination and Influence, edited by Jolanta Guzy-Pasiak and Aneta Markuszewska, 183-197. Warsaw: Liber Pro Arte, 2016.

Keller, Katrin. Erzherzogin Maria von Innerösterreich (1551-1608): Zwischen Habsburg und Wittelsbach. Vienna: Böhlau, 2012. https://doi.org/10.7767/boehlau.9783205791966.

Kokole, Metoda. "Echoes of Giovanni Gabrieli's Style in the Territories between Koper and Graz in the First Quarter of the Seventeenth Century". In Giovanni Gabrieli: Transmission and Reception of a Venetian Musical Tradition, edited by Rodolfo Baroncini, David Bryant and Luigi Collarile, 51-67. Venetian music studies, 1. Turnhout: Brepols, 2016.

—. "From Graz to Today's Central Slovenia: The Influence of Italian Polychoral Music in the Period c. 1595 to c. 1620”. In La musica policorale in Italia e nell'Europa centro-orientale fra Cinque e Seicento / Polychoral Music in Italy and in CentralEastern Europe at the Turn of the Seventeenth Century, edited by Aleksandra Patalas and Marina Toffetti, 335-374. TRA.D.I.MUS, Studi e monografie, 1. Venice: Fondazione Levi, 2012.

- Isaac Posch "diditus Eois Hesperiisque plagis - Praised in the Lands of Dawn and Sunset”. Frankfurt am Main: Peter Lang, 2009.

- "The Musical Repertoire Cultivated on the Territory of Modern Slovenia (1567ca. 1620) and Its Possible Connections with the Court Chapel in Munich". In Die Münchner Hofkapelle des 16. Jahrhunderts im europäischen Kontext: Bericht über das internationale Symposion der Musikhistorischen Kommission der Bayerischen Akademie der Wissenschaften in Verbindung mit der Gesellschaft für Bayerische Musikgeschichte, München, 2.-4. August 2004, edited by Theodor Göllner and Bernhold Schmid, 171-190. Munich: Verlag der Bayerischen Akademie der Wissenschaften and Kommission bei C. H. Beck, 2006.

- "Venetian Influence on the Production of Early-Baroque Monodic Motets in the Inner-Austrian Provinces". Musica e Storia 8 (2000): 477-507.

https://doi.org/10.1420/12499

Koldau, Linda Maria. Frauen - Musik - Kultur: Ein Handbuch zum deutschen Sprachgebiet der Frühen Neuzeit. Cologne: Böhlau Verlag, 2005.

Priuli, Giovanni. Vier Generalbaßmotetten aus dem Parnassus Musicus Ferdinandaeus (1615), edited by Hermann J. Busch. Musik alter Meister, 23. Graz: Akademische Druck- u. Verlagsanstalt, 1970.

Puliti, Gabriello. Baci ardenti (1609), Armonici accenti (1621). Edited by Bojan Bujić and Ennio Stipčević. Monumenta artis musicae Sloveniae, 44. Ljubljana: Slovenska akademija znanosti in umetnosti, Muzikološki inštitut Znanstvenoraziskovalnega centra Slovenske akademije znanosti in umetnosti, 2003.

Przybyszewska-Jarminska, Barbara. The History of Music in Poland. Vol. 3, The Baroque, part 1: 1595-1696. Warsaw: Sutkowski Edition, 2002.

Saunders, Steven. Cross, Sword, and Lyre: Sacred Music at the Imperial Court of Ferdinand II of Habsburg (1619-1637). Oxford: Clarendon Press, 1995. 
__ - ed. Fourteen Motets from the Court of Ferdinand II of Hapsburg. Recent Researches in the Music of the Baroque Era, 75. Madison: A-R Editions, 1995.

Staudacher, Isle M. "Musik in Graz von den Anfängen biz zur Gegenwart”. In KircheBildung - Kultur, edited by Walter Brunner, 661-728. Geschichte der Stadt Graz, 3. Graz: Stadt Graz, 2003.

Szweykowska, Anna, and Zygmunt M. Szweykowski. Włosi w kapeli królewskiej polskich Wazów [Italians in the royal chapel of the Polish Vasa Kings]. Cracow: Musica Iagellonica, 1997. 


\section{PARNAS NADVOJVODE FERDIANADA V GRADCU}

\section{Povzetek}

Leta 1615 , ko je urednik notranjeavstrijskemu nadvojvodi Ferdinandu posvečenega glasbenega tiska le-tega naslovil "Ferdinandov glasbeni Parnas", je bil njegov dvor v Gradcu že vsesplošno znan kot umetniški Parnas, kraj druženja muz oz. umetnikov, predvsem glasbenikov. Prispevek podaja kratek pregled in vpogled v razvejano mrežo glasbenikov in njihovih povezav z graško dvorno kapelo oziroma z vladarjem Ferdinandom in člani njegove družine med približno 1598 in 1619.

Kljub temu, da je bila leta 1590 glasbena kapela njegovega očeta Karla - dvor slednjega in njegove soproge Marije Bavarske v glasbenem okusu in zanimanju za vrhunsko glasbo svojega časa ni dosti zaostajal za sinovim - razpuščena, jo je Ferdinand kmalu po prevzemu vladavine 1696 obudil, jo povečal iz prejšnjih 18 članov na 53 v letu 1619, jo posodobil ter ji dal še večji sijaj in pomen, osnovo za pozneje cvetočo glasbeno kapelo enega najpomembnejših evropskih dvorov, cesarsko dvorno kapelo na Dunaju.

Glasbena kapela je delovala po točno določenem vzorcu in je bila urejena strogo hierarhično. Vodil jo je kapelnik, ki je moral biti tudi skladatelj in je s pomočjo pomočnika skrbel tudi za deške pevce. V obravnavanem času sta bila to Pietro Antonio Bianco (kapelnik med 1595 in 1611) in Giovanni Priuli (1614/15 do odhoda na Dunaj 1519). Tako kapelnik kot tudi drugi vodilni glasbeniki, organisti (npr. Giovanni Valentini) in inštrumentalisti, od katerih jih je mnogo tudi skladalo, so prihajali iz svetovnega glasbenega središča italijanskih Benetk ali pa so bili tam oz. v severni Italiji glasbeno šolani.

Glasbeni Parnas v Gradcu pa ni bil le dom teh glasbenikov, temveč so k razcvetu glasbene umetnosti v njem prispevali tudi številni drugi skladatelji, ki so svoja dela namenjali oziroma posvečali glasbi naklonjenemu vladarju Ferdinandu in njegovi družini. Ta repertoar je znan iz ohranjenih glasbenih tiskov, rokopisov, inventarjev in drugih arhivskih virov.

Med okoli dvajsetimi glasbenimi deli, ki so bila med 1597 in 1619 posvečena nadvojvodi Ferdinandu oz. njegovi družini, so jih deset prispevali njegovi dvorni glasbeniki, na primer Simone Gatto, Annibale Perini, Raimundo Ballestra, Giovanni Valentini in Giovanni Priuli. Vsa posvetilna pisma, ki običajno uvajajo glasbene tiske, hvalijo Ferdinandov izjemen glasbeni okus, visoke standarde in seveda naklonjenost in darežljivost do glasbenikov.

Med omenjenimi posvetilnimi tiski izstopa zbirka devetnajstih madrigalov graškega dvornega organista Francesca Stivorija Musica austriaca. Ustvaril jo je poleti leta 1604 ter jo maja 1605, le malo pred svojo smrtjo, naslovil na Ferdinandovo mater, vdovo Marijo. Zbirko so očitno pri skladatelju naročili Marijini otroci, vsi glasbi naklonjeni in povezani z nekaterimi najpomembnejšimi evropskimi posvetnimi in cerkvenimi dvori ter glasbenimi središči: španskim, poljskim, toskanskim, bavarskim, transilvanskim itd. Skladatelj kar v dvanajstih madrigalih tudi glasbeno slavi "neprimerljivo pomembnost in vrline" raznih takrat živečih in tudi že umrlih članov Marijine "hiše"; seveda tudi najstarejšega sina Ferdinanda, ki mu je namenil najmogočnejšo skladbo za kar šestnajst glasov in verjetno štiri zbore. 
Med glasbenimi deli oz. tiski, posvečenimi Ferdinandu, po številu avtorjev in neposredni omembi Ferdinandove naklonjenosti glasbi in mogočnosti njegovega glasbenega Parnasa izstopa antologija Parnassus musicus Ferdinandaeus, ki jo je dal 1615 v Benetkah natisniti Giovanni Battista Bonometti, iz lombardskega kroga izhajajoč glasbenik in pevec graške dvorne kapele. V njej je objavil 57 motetov za enega do štiri glasove in basso continuo 32 pretežno italijanskih skladateljev. Poleg velikega števila lombardskih skladateljev je slabo tretjino motetov prispevalo devet graških dvornih glasbenikov, poleg kapelnika Priulija še prvi organist Valentini, pa Bartolomeo Musit, Giovanni Sansoni, Michelangelo Rizzi ter Georg Poss, Raimundo Ballestra in Alessandro Tadei. V zbirki ne manjka niti motet slavnega Claudia Monteverdija, katerega ime daje Ferdinandovemu Parnasu še posebno težo. 